\title{
Interlanguage Errors Based on the Source of Errors in Indonesian College Students' Pronunciation
}

\author{
Arian Pramesta Harunika*, Zulfa Sakhiyya, Rudi Hartono \\ Universitas Negeri Semarang, Indonesia \\ *Email: violinarian@gmail.com
}

DOI https://doi.org/10.15294/lc.v15i1.25887

Submitted 26 August 2020. Revised 30 September 2020. Accepted 18 October 2020

\begin{abstract}
This study aimed to explore the source of IL errors on male and female students' pronunciation. The participants in this research were ten college students who were participated in an English speech contest organised by English Student Association of UNNES 2019. The ten participants consist of five male and five female students who came from different kinds of University in Indonesia. In this study, the researcher used a descriptive qualitative method to analyze the data by using a video recorder as an instrument to collect the data. The result of this research showed that there were four sources of errors which influenced male and female students in producing IL errors on pronunciation. Those were L1 transfer, different form of plural between L1 and L2, the existence of sounds with the same phonetic features but different in distribution, and English foreign sounds. The second result described that the source of errors on male and female college students was mostly similar, and they had no significant differences. Last result showed that male students made more variation of IL errors on their pronunciation than female students.
\end{abstract}

Keywords: IL errors; pronunciation; male and female students; source of errors

\section{INTRODUCTION}

Pronunciation is a key component in English speaking proficiency because incorrect pronunciation may potentially lead to miscommunication and communication breakdown. English pronunciation is complex because it has its own phonological rules and different system of alphabets, word spelling and sound distributions in which they are totally different compare to Indonesian pronunciation. These factors lead into unintelligible pronunciation, in which this is in contrast with the goal of learning pronunciation. Yuzawa, (2007, as cited in Sibaja, 2019) said that intelligible English pronunciation is a basic and essential skill required for L2 learners. Moreover, Gilakjani (2012) added that good pronunciation leads into great learning while bad pronunciation leads into great difficulties in language learning.

Through pronunciation instruction, learners not only learn different sounds and sound features but also improve their speaking proficiency that lead into good communication. As Fabianto and Hartono (2015) stated, English is an International language in which people must have appropriate English skill in speaking, and pronunciation has an essential role in it.
Seidlhofer (2005, as cited in Sakhiyya, 2018) explained that English as a lingua franca refers to any communication in English which are carried out by speakers with different first language. In one hand, college students mostly received proper pronunciation coaching in English education program which can help them to acquire good pronunciation to improve their speaking proficiency. But, on the other hand, college students who learn English pronunciation as the second language are mostly dealing with errors in their target language (TL). As a result, the development of Indonesian students in using English is very unique (Sakhiyya, 2018). It means that students will create new unique languages between L1 and TL which is called as Interlanguage (Selinker, 1972).

Interlanguage is a kind of error. This is supported by Brown (1980) who said that errors are noticeable grammar from the old grammar of a native speaker in which they reflect as the Interlanguage competence of learners. In this case, gender plays a very important role in second language acquisition especially in error production (Llach, Fontecha, \& Espinosa, 2006). Litosseliti (2013) supported by stating that the early prefeminist linguistic research views that women's 
and men's language signals biological differences and symbolizes social gender roles. In this case, there is a basic clear difference between male's and female's language which draw them to make errors.

Interlanguage (IL) itself was introduced by an American linguist Larry Selinker in 1972. Interlanguage (IL) refers to a new language produced by language learners as the target language. It is a language between native language or source language (SL) and target language (TL) which is built by learners as their own system of language. According to Trawinki (2005, as cited in Yelfiza, 2016), Interlanguage is known as the language system which the learner constructs in the process of SLA.

According to Cook (1996), pronunciation is the production of English sound. Cook gives general definition and does not mention in detail what kind of sound produced in pronunciation. Another expert, Yates (2002, as cited in Gilakjani, 2016) added the definition of pronunciation as the production of sound that is used for making meaning. In another word, pronunciation is the production of English sounds in speaking and listening to make meaning.

In speaking generally, and pronunciation practice especially, students may make some IL errors. Brown (1980) described errors as noticeable grammar from the old grammar of a native speaker in which they reflect as the Interlanguage (IL) competence of learners.

There are some studies have been conducted on IL errors based on gender. The first was a study based on gender to pronunciation accuracy of advanced EFL learners conducted by Jahandar et. al. (2012). This study aimed to analyze the impact of gender on pronunciation accuracy of advanced learners. The result of the study revealed that gender did not affect pronunciation accuracy of learners and the pronunciation accuracy of vowels for both male and female students were not of significant difference and were almost the same. But, from the result, the researchers noticed that female outperform male subjects in producing accurate consonants, but it was not significantly noticeable.

Another previous study was conducted by Zimman (2013), a researcher from University of Colorado at Boulder. He did a research on pronunciation of /s/ sounds which impacts perception of gender. He collected the data by recording the voices of 15 transgender men who lived in San Francisco and analyzed the data by software developed by fellow linguists. The result was 10 listeners considered that the speakers were men due to the low pitch that they had. In conclusion, pitch takes a role in determining gender in pronunciation.

Other researchers were also carried out a study about gender and reduced speech with different finding (Gowhary et al., 2016). They conducted a study to observe the effects of gender, experience and academic degree on the vowel reduction in derivative and function words. In this study, the researchers focused on vowel reduction because they considered it as an important aspect in pronunciation to build a good communication and make the speech easily intelligible and native-like. The result of this study revealed that males were better in pronouncing reduced vowels than females.

The last study was carried out by Alahmadi and Lahlali (2019) who conducted a study about the role of learners' gender differences in Interlanguage errors of intermediate-level Saudi language learners. Their study focused on analyzing and classifying learners' error in speaking skill and examining the Interlanguage errors produced by male and female students to highlight the role of gender.

Some of the previous studies only focused on students' errors on pronunciation based on gender. While this study aimed to not only focus on students' pronunciation errors but also revealed the source of errors they made and the similarities and differences between the source of errors between males and females students.

\section{METHODS}

In this study, the researcher applied a descriptive qualitative method. A comparative analysis also applied for this study since the researcher intended to compare two variables (male and female). The researcher conducted the research on ESA (English Student Association) Speech Contest which was held in UNNES in the 20th of October 2019. The participants in this research were five male and five female students from different Universities who were registered as English speech contestants.

The type of data collection used in this research was observation. In addition, the researcher used video recorder as the instrument to collect the data. The researcher did some steps in analyzing the data such as: recording the speech from some participants, selecting ten speeches as samples, classifying the speeches into male and female categories, transcribing the recorded speech, finding out the IL errors, classifying the IL errors based on the source of errors and evalu- 
ating the results.

\section{RESULTS AND DISCUSSION}

The IL errors occurred on male and female students based on the source of errors

Based on the findings from the transcribed speeches, the researcher found some sources of errors on male and female students' speeches. The first was L1 transferred. Male and female students transferred letter "i" which should be pronounced as /I/ sound into /i/ sound. Vowel /I/ does not exist in Indonesian vowel sound, so they transfer /I/ sound into the nearest vowel sound they have in Indonesian from unrounded half-close to close front vowel become unrounded close front vowel. Though vowel /I/ is not really difficult to pronounce as mentioned by Syafei
(1998, as cited in Barokah, 2020), but this vowel /I/ is problematic since students have lack practice in pronouncing this vowel sound. Students also made IL errors on the vowel /ə/. They substituted $/ \ni /$ sound into $/ \mathrm{J} / \mathrm{J} / \mathrm{J} /$, and $/ \Lambda /$ sound. Researcher saw this as the result of L1 transfer. Because as we know that vowel /ə/ does not exist in Indonesian vowel so that they transferred into another vowel they have in their mother tongue. In this case, they transferred vowel $/ \ni /$ into vowel $/ \mathrm{J} /, / \mathrm{J} /, / \Lambda /$ and $/ \varepsilon /$, vowel $/ \Lambda /$ into vowel $/ \mathrm{J} /$, diphthong /ov/, and vowel $/ \mho /$. Vowel /ə:/ into vowel $/ \mathrm{s} /$. Vowel $/$ i: / into vowel $/ \varepsilon /$. Vowel $/ \varepsilon /$ into diphthong /aI/ and vowel /is/. Vowel /o:/ into diphthong /av/ and vowel / $/: /$. / $: /$ sound into $/ \mathrm{v} /$ sound.

Moreover, the researcher found that the English alphabet was so complicated for them

Table 1. L1 Transfer of Male Students

\begin{tabular}{|c|c|c|}
\hline $\begin{array}{l}\text { English } \\
\text { Sound }\end{array}$ & $\begin{array}{l}\text { Sound } \\
\text { Substitution }\end{array}$ & Example of Words \\
\hline$/ \mathrm{I} /$ & /i/ & $\begin{array}{l}\text { is, fortunately, with, notice, it, feeling, habit, till, only, this, intellectual, } \\
\text { university, income }\end{array}$ \\
\hline /ə/ & $/ \mathrm{u} /$ & previous, focus \\
\hline /ə/ & $/ \mathrm{j} /$ & technology, continue, community, history \\
\hline /ə/ & $/ \varepsilon /$ & judges, incident, material \\
\hline /ə/ & $/ \mathrm{I} /$ & possible, judges, changes, community \\
\hline /ə/ & $/ \Lambda /$ & data \\
\hline$/ \Lambda /$ & $/ \mathrm{s} /$ & honourable, country \\
\hline$/ \Lambda /$ & lov/ & country \\
\hline$/ \Lambda /$ & $/ v /$ & multiple, industrial \\
\hline /ə:/ & $/ \mathrm{s} /$ & work \\
\hline /i:/ & $/ \varepsilon /$ & senior \\
\hline $\mid \varepsilon /$ & /ai/ & said \\
\hline$/ \varepsilon /$ & /i:/ & tenth \\
\hline /J:/ & /av/ & audience, because \\
\hline /כ:/ & /v:/ & source \\
\hline /U:/ & $/ \mathrm{u} /$ & use, community \\
\hline /av/ & $/ \mathrm{j} /$ & so, focus, moment \\
\hline /eI/ & $/ \varepsilon /$ & notification, transportation \\
\hline /eI/ & $/ \Lambda /$ & data \\
\hline /z/ & $/ \mathrm{s} /$ & $\begin{array}{l}\text { judges, always, because, previous, intelligence, is, example, ideas, stands, } \\
\text { ladies, reasons, does, use, wise, was, easy, realize, means }\end{array}$ \\
\hline$/ \mathrm{b} /$ & $/ \mathrm{p} /$ & YouTube, job \\
\hline$/ \mathrm{p}^{\mathrm{h}} /$ & $/ \mathrm{p} /$ & $\begin{array}{l}\text { passion, people, proud, piece, passenger, pick up, people, popular, prepa- } \\
\text { ration, pioneer }\end{array}$ \\
\hline /v/ & /f/ & $\begin{array}{l}\text { ever, university, provide, predictive, save, believe, live, even, have, every, } \\
\text { vacation, Java, live, development, innovator, university, invite }\end{array}$ \\
\hline
\end{tabular}


Table 2. L1 Transfer of Female Students

\begin{tabular}{|c|c|c|}
\hline $\begin{array}{l}\text { English } \\
\text { Sound }\end{array}$ & $\begin{array}{l}\text { Sound Substi- } \\
\text { tut-ion }\end{array}$ & Example of Words \\
\hline /I/ & /i/ & $\begin{array}{l}\text { suddenly, predictive, notice, video, watching, imagine, it, notification, } \\
\text { lazy, empathy, in, being, increase, if, still, ship, this, internet, facing, } \\
\text { things, English, commonly, only }\end{array}$ \\
\hline$/ \mathrm{I} /$ & $\mid \varepsilon /$ & development \\
\hline /ə/ & $/ \mathrm{v} /$ & previous, curious \\
\hline /ə/ & $/ \mathrm{s} /$ & technology \\
\hline /a/ & $\mid \varepsilon /$ & competence, obstacle \\
\hline /a/ & $/ \Lambda /$ & dramatically, social, media \\
\hline $\mid \Lambda /$ & $/ \mathrm{J} /$ & other, another, country, problem, nothing \\
\hline$/ \Lambda /$ & /ə/ & heart \\
\hline$/ \Lambda /$ & $/ \mathrm{v}$ & multiple, industrial \\
\hline /i:/ & $\mid \varepsilon /$ & media, increase \\
\hline $\mid \varepsilon /$ & /ai/ & said \\
\hline /э:/ & /av/ & audience, because \\
\hline /כ:/ & $/ 0: /$ & source \\
\hline /U:/ & $/ \mathrm{v} /$ & YouTube \\
\hline /av/ & $/ \mathrm{s} /$ & account, about, so, social, go \\
\hline /ei/ & $\mid \varepsilon /$ & notification, face, later \\
\hline$/ \mathrm{z} /$ & /s/ & $\begin{array}{l}\text { judges, always, because, previous, intelligence, is, example, has, was, } \\
\text { because, friends, nowadays, as, personalize, teachers, trainers, hands, } \\
\text { organization, utilize, ladies, learners, using }\end{array}$ \\
\hline$/ \mathrm{b} /$ & $/ \mathrm{p} /$ & YouTube \\
\hline$/ \mathrm{t}^{\mathrm{h}} /$ & $/ \mathrm{t} /$ & that, later, tell \\
\hline$/ \mathrm{p}^{\mathrm{h}} /$ & $/ \mathrm{p} /$ & person, past, pay \\
\hline$/ \mathrm{k}^{\mathrm{h}} /$ & $/ \mathrm{k} /$ & teamwork, can \\
\hline$/ \mathrm{v} /$ & /f/ & $\begin{array}{l}\text { provide, conversation, video, motivation, interactive, revolution, sur- } \\
\text { vive, everyone, giving, deliver, revolution, everything, even, have, level } \\
\text { evaluate, provide }\end{array}$ \\
\hline
\end{tabular}

and Indonesian as new learners has different background of alphabet (Ellis, 1999). Next findings show that L1 transfer also occurred on the diphthong substitutions of male and female students. They substituted diphthong /ov/ into /J/ sound and diphthong /ei/ into $/ \Lambda /$ sound. These phenomena caused by L1 transfer because Indonesian does not have diphthong /ou/ and /ei/.

Another finding shows that students made IL errors on the consonant substitutions. They substituted /z/ sound into /s/ sound, /b/ sound into $/ \mathrm{p} /$ sound, $/ \mathrm{p}^{\mathrm{h}} /$ sound into $/ \mathrm{p} /$ sound, and /v/ sound into /f/ sound. More detail explanation was displayed in the following Table $1 \& 2$.

The second source of errors is different form of plurals. English has three different ways in pronouncing the plural sounds, in which it will include three allomorphs. The way to pronounce the plural nouns is vary as Table 3.

While Indonesian does not need any allomorph to mention the plural noun. Alwi et. al. (2000, as cited in Humaini, A., 2016) explained that plural markers in Indonesian is marked by the noun repetition, adjective repetition, and the use of number and quantifier as displayed in the Table 4. As a result, Indonesian students made errors in pronouncing some plural words as displayed in the following Figure 1.

The third source of errors on male and female students' pronunciation is sound with the same phonetic features but different in distribution. The first is letter "s". In English, letter "s" can be pronounced as voiced / $\mathrm{z} /$ or voiceless /s/. Letter "s" in English plural suffix is pronounced 
Table 3. English Plural Form Pattern

\begin{tabular}{|c|c|c|}
\hline Allomorph & Environment & Example \\
\hline$|z|$ & After voiced non sibilant segments & /kæbz/, /bægz/ \\
\hline$/ \mathrm{s} /$ & After voiceless non sibilant segments & /kæps/, /kæts/ \\
\hline |əz/ & After sibilant segments & /bısəz/, /bufəz/ \\
\hline
\end{tabular}

Table 4. Indonesian Plurals Form Patterns

\begin{tabular}{llll}
\hline Noun/ Noun Phrase & Noun repetition & Adjective Repetition & $\begin{array}{l}\text { Number addition \& } \\
\text { Quantifier }\end{array}$ \\
\hline Teman & teman-teman & - & dua teman \\
Guru & Guru-guru & - & Beberpa guru \\
Pelatih & pelatih-pelatih & - & para pelatih \\
Tangan & tangan-tangan & - & - \\
Anak lucu & - & anak yang lucu-lucu & - \\
\hline
\end{tabular}

Table 5. IL Errors on Students' Plural Forms

\begin{tabular}{cc}
\hline Male Students & Female Students \\
\hline judges /dzıdzıs/ & judges /dz^dzis/ \\
ideas /ar'dıəs/ & Friends /frends/ \\
- & teachers /'ti..tjərs/ \\
- & trainers /'trei.nərs/ \\
- & hands /hænds/ \\
- & ladies /'leı.dis \\
\hline
\end{tabular}

as /s/ sound after a voiceless sound, while it is pronounced as $/ z /$ sound after a voiced sound. This is a kind of assimilation rules mentioned by Fromkin et. al. (2011, p. 247). McMahon (2002, p.41) added that letter "s" can be either voiced or voiceless sound. While in Indonesian, letter "s" always pronounced as voiceless /s/ sound. As a result, students made IL errors on the sound substitution of consonant /s/ such as in the: words: always /'כ:1.wers/, has /bıs/, wise /wars/, realize /'riə.lars/, does/dıs/, use /juss/, was/wos/, is /Is/.

In addition, voiced sound/z/ occurs at utterance initial, medial, and final position such as in the words: zipper /'zip.ər/, measure /'mez.ər/. But on the contrary, in Indonesian, /z/ sound mostly only occurs at the initial and medial utterance and never occur on the final position, for instance in the words: zebra, zaman, ijazah. In the word "jazz" in which letter " $z$ " in the final position should be pronounced as / $z$ / sound, Indonesian pronounces it as /s/ sound, a voiceless blade-alveolar fricative because they gets difficulty in pronouncing the voiced sound in the final utterances.

The next finding shows the dilemmatic sound of /f/ and /v/ sounds. These two sounds are totally different in the distribution in English. /f/ sound is a voiceless labio-dental fricative and $/ \mathrm{v} /$ sounds is a voiced labio-dental fricative. While in Indonesian, /f/ and / $/$ sounds are pronounced as voiceless. Because the English consonant / $/$ cannot be found in Indonesian phonetic system. This is supported by Nesgoda (1980, as cited in Tiono, 2008) who stated that language learners may find difficulties in learning to speak English well because several spelling may be represented by a single sound. As a result, students made IL errors on some words: ever /'ef.ər/, university /jui.nı'f3r.sə.ti/, provide /pro'fard/, predictive /pri'drk.trf/, save /serf/, believe /br'liff/, live /lif/. Students pronounced the letter "v" in those words as /f/ sound just like pronouncing /f/ sound in Indonesian words: vespa / $\mathrm{fssp}_{\mathrm{s}} /$, variasi /f $\Lambda$ riısi/, diva /dif $\Lambda$ /, dove /d $\Lambda \mathrm{f} /$ (a brand of soap).

The next sound which has the same phonetic features but different in distribution is letter "b" or /b/ sound, a voiced bilabial stop. In English, /b/ sound pronounced to be /b/ sound in the initial, medial, and final utterances such as in the words: bold, embrace, job. But in Indonesia, letter ' $b$ ' for $/ b /$ sound only pronounced as $/ \mathrm{b} /$ sound when it is positioned in the initial 
and medial utterances such as in the words: buat, membuat, hebat. While the letter ' $b$ ' in which positioned in the final position is pronounced as $/ \mathrm{p} /$ sound due to the difficulty of Indonesian students to pronounce a voiced stop sound in the final utterance as mentioned by Ramelan (1999, p. 6) such as the words: adab / $\Lambda \mathrm{d} \Lambda \mathrm{p} /$, bab /b $\Lambda \mathrm{p} /$, sebab /səbıp/.

Moreover, letter 't', 'p', and 'k'or /t/, /k/, and $/ \mathrm{p} /$ sounds also have the same phonetic features but different in the distribution. These sounds are voiceless stop consonants which have more than one variant. Fromkin (2011) saw this phenomenon as the allophone of consonant. In the stressed syllable, /t/, /p/, and /k/ are aspirated or pronounced by slightly puff of breath/ $\mathrm{t}^{\mathrm{h}} /, / \mathrm{p}^{\mathrm{h}} /, / \mathrm{k} /$, but in unstressed syllable, ' $\mathrm{t}$ ', 'p', and ' $\mathrm{k}$ ' pronounced as un aspirated. Fromkin (2011) said this is a kind of feature-changing rules in phonology. /. McMahon (2002) added that $\mathrm{t} /$, $/ \mathrm{p} /$, and $/ \mathrm{k} /$ are aspirated become $/ \mathrm{t}^{\mathrm{h}} /, / \mathrm{p}^{\mathrm{h}} /, /$ $\mathrm{k}^{\mathrm{h}} / \mathrm{at}$ the very beginning of a word. On the contrary, /t/, /p/, and /k/ sounds will be non-aspirated when they are located after /s/ sound: still /stıl/, spill /spil/, skill /skıl/. In another variant, $/ \mathrm{t} /, / \mathrm{p} /$, and $/ \mathrm{k} /$ sounds can be mute: fasten / farsn/, bustle /ba:sl/, often /.jn/.

Aspiration in English is non predictable so that Indonesian college students got difficulty and made IL errors dealing with sounds such as in the words: passion /'pæf.ən/, people /'pi:. pəl/, proud /praud/, piece /pirs/, passenger / 'pæs.ən.dzər/,pick /pik/, people /'pi..pəl/, popular /'ppp.jə.lər/, preparation /,prep.ər'eI.Jən/, pioneer /,paiə'nıər/. In these words, male and female students pronounced /p/ sound as nonaspirated sound.

The last source of error is foreign sound. The finding shows that male and female students made errors in pronouncing foreign sounds such as: /æ/, /3/, / eI/, /iə/, / $/$ /, and /t $\int /$ sound. Syafei (1998, as cited in Barokah, 2020) added that Indonesian students got difficulty in pronouncing $/ æ /, / 3 /, /$ eI/, /iə/, / $/ \theta /$, and $/ \mathrm{t} \int /$ sound since Indonesian doesn't have this kind of sound. Students' organs of speech also got difficulty to produce these sounds since these foreign sounds are not similar with Indonesian vowel sound (Ramelan, 1999). As a result, male and female students made IL errors on these foreign sounds. More detail information is displayed in the Table 6.

\section{Similarities on the Source of Errors on male and female Students' Pronunciation}

From the findings in the previous explanation, the researcher found many similarities between male and female students in the source of errors. L1 transfer influences both male and female students' IL errors on the similar sound substitution on vowels, diphthongs, and consonants. These similarities occurred because they come from the same mother tongue L1 in which they share the same problems and obstacle in pronouncing English sounds as their L2. Most of them made the same errors on the sound substitution as captured in the Table 7.

Next similarities found in IL errors on male and female students on the plural forms. Most students made errors in pronouncing / $\mathrm{z} /$ and /əz/ sound in the plural forms, such as in the words: judges /dz 1 dzIs/, ideas /aI'diəs/, friends /frends/, teachers /'tirtfərs/, trainers /'treI.nərs/, hands /hænds/, ladies /'leı.dis/.

The third similarity found on difficulties faced by male and female students on sounds which have same phonetic features but different in their distribution such as: /z/, /p, /b, /t/,

Table 6. IL Errors of Male and Female Students on the Foreign English Sounds

\begin{tabular}{|c|c|c|}
\hline Sounds Substitutions & Male Students & Female Students \\
\hline $\mid æ /-/ \varepsilon /$ & passion, as, gadget, transportation & that, as, passion \\
\hline$|3|-|s|$ & usually & - \\
\hline $\mid 3 /-/ \mathrm{y} /$ & - & change \\
\hline$|\mathrm{eI} /-| \varepsilon /$ & notification, transportation & notification, face, later \\
\hline $\mid \mathrm{eI} /-/ \Lambda /$ & data & - \\
\hline /iə/ - / $/ \varepsilon /$ & experience & experience \\
\hline /iә/ - /丂/ & junior, senior & \\
\hline /іә/ -/ə/ & - & materials \\
\hline $\mid \theta /-/ t /$ & empathy, with, think, thank, through & trainers /'trei.nərs/ \\
\hline$/ \mathrm{t} \int /-/ \mathrm{t} /$ & fortunately & hands /hænds/ \\
\hline$/ \mathrm{t} \mathrm{J} /-/ \mathrm{s} /$ & question & - \\
\hline
\end{tabular}


Table 7. Similarities of IL Errors on Male and Female Students Based on L1 Transfer

\begin{tabular}{|c|c|c|c|}
\hline $\begin{array}{l}\text { English } \\
\text { Sound }\end{array}$ & $\begin{array}{l}\text { Sound Sub- } \\
\text { stitution }\end{array}$ & Words found on Male & Words found on Feale \\
\hline$/ \mathrm{I} /$ & /i/ & $\begin{array}{l}\text { is, fortunately, with, } \\
\text { notice, it, feeling, habit, } \\
\text { till, only, this, intellectual, } \\
\text { university, income }\end{array}$ & $\begin{array}{l}\text { suddenly, predictive, notice, video, watching, } \\
\text { imagine, it, notification, lazy, empathy, in, } \\
\text { being, increase, if, still, ship, this, internet, fac- } \\
\text { ing, things, English, commonly, only }\end{array}$ \\
\hline /ə/ & $/ v /$ & previous, focus & previous, curious \\
\hline /ə/ & $/ \mathrm{J} /$ & $\begin{array}{l}\text { technology, continue, } \\
\text { community, history }\end{array}$ & technology \\
\hline /ə/ & $\mid \varepsilon /$ & judges, incident, material & competence, obstacle \\
\hline /ə/ & $/ \Lambda /$ & data & dramatically, social, media \\
\hline$/ \Lambda /$ & $/ \mathrm{J} /$ & honourable, country & other, another, country, problem, nothing \\
\hline$/ \Lambda /$ & /ou/ & country & \\
\hline$/ \Lambda /$ & $\mid \mathrm{u} /$ & multiple, industrial & multiple, industrial \\
\hline $\mid \varepsilon /$ & /aI/ & said & said \\
\hline /כ:/ & /av/ & audience, because & audience, because \\
\hline /ว:/ & /U:/ & source & source \\
\hline /U:/ & $/ v /$ & use, community & YouTube \\
\hline /av/ & $/ \mathrm{J} /$ & so, focus, moment & account, about, so, social, go \\
\hline /ei/ & $\mid \varepsilon /$ & $\begin{array}{l}\text { notification, transporta- } \\
\text { tion }\end{array}$ & notification, face, later \\
\hline /z/ & /s/ & $\begin{array}{l}\text { judges, always, because, } \\
\text { previous, intelligence, is, } \\
\text { example, ideas, stands, } \\
\text { ladies, reasons, does, use, } \\
\text { wise, was, easy, realize, } \\
\text { means }\end{array}$ & $\begin{array}{l}\text { judges, always, because, previous, intelligence, } \\
\text { is, example, has, was, because, friends, nowa- } \\
\text { days, as, personalize, teachers, trainers, hands, } \\
\text { organization, utilize, ladies, learners, using }\end{array}$ \\
\hline$/ \mathrm{b} /$ & $/ \mathrm{p} /$ & YouTube, job & YouTube \\
\hline$/ \mathrm{p}^{\mathrm{h}} /$ & $/ \mathrm{p} /$ & $\begin{array}{l}\text { passion, people, proud, } \\
\text { piece, passenger, pick up, } \\
\text { people, popular, prepara- } \\
\text { tion, pioneer }\end{array}$ & person, past, pay \\
\hline /v/ & $/ \mathrm{f} /$ & $\begin{array}{l}\text { ever, university, provide, } \\
\text { predictive, save, believe, } \\
\text { live, even, have, every, } \\
\text { vacation, Java, live, } \\
\text { development, innovator, } \\
\text { university, invite }\end{array}$ & $\begin{array}{l}\text { provide, conversation, video, motivation, } \\
\text { interactive, revolution, survive, everyone, giv- } \\
\text { ing, deliver, revolution, everything, even, have, } \\
\text { level, evaluate, provide }\end{array}$ \\
\hline
\end{tabular}

$/ \mathrm{k} /, / \mathrm{f} /, / \mathrm{v} /$. As a result, they made errors on these English sounds. They substituted / $\mathrm{z} /$ into $/ \mathrm{s} /$ sound, $/ \mathrm{p} /$ into $/ \mathrm{b} /$ sound, as displayed in the figure below: $/ \mathrm{p}^{\mathrm{h}} /$ into $/ \mathrm{p} /, / \mathrm{k}^{\mathrm{h}} /$ into $/ \mathrm{k} /$, $/ \mathrm{v} /$ into /f/ as displayed in the Table 8.

And the last similarity was both male and female students made the same errors in pronouncing foreign sounds such as: $/ \mathrm{v} /, / \theta /, / ð /$, $/ 3 /$, and $/ \mathrm{d} 3 /$. They got difficulty in pronouncing these sounds because their organs of speech didn't use to pronounce them and also got difficulty to produce these sounds as mentioned by Ramelan (1999).

\section{Differences on the Source of Errors on male and female Students' Pronunciation}

Differences are not significantly found between male and female students in producing IL errors on their pronunciation. What the researcher found was only the different variation of 
Table 8. Similarities of IL errors on Male and Female Students Based on the Sounds with same phonetic features but different in their distribution

\begin{tabular}{|c|c|c|}
\hline $\begin{array}{l}\text { English Sound's } \\
\text { Substitution }\end{array}$ & Words found on Male & Words found on Female \\
\hline /z/ - /s/ & $\begin{array}{l}\text { judges, always, because, previous, } \\
\text { intelligence, is, example, ideas, } \\
\text { stands, ladies, reasons, does, use, } \\
\text { wise, was, easy, realize, means }\end{array}$ & $\begin{array}{l}\text { judges, always, because, previous, intel- } \\
\text { ligence, is, example, has, was, because, } \\
\text { friends, nowadays, as, personalize, teachers, } \\
\text { trainers, hands, organization, utilize, ladies, } \\
\text { learners, using }\end{array}$ \\
\hline$/ \mathrm{b} /-/ \mathrm{p} /$ & $\begin{array}{l}\text { YouTube, } \\
\text { Job }\end{array}$ & YouTube \\
\hline$/ \mathrm{p}^{\mathrm{h}} /-/ \mathrm{p} /$ & $\begin{array}{l}\text { passion, people, proud, piece, pas- } \\
\text { senger, pick up, people, popular, } \\
\text { preparation, pioneer }\end{array}$ & person, past, pay \\
\hline$/ \mathrm{k}^{\mathrm{h}} /-/ \mathrm{k} /$ & $\begin{array}{l}\text { Teamwork } \\
\text { Can }\end{array}$ & $\begin{array}{l}\text { Can } \\
\text { Could }\end{array}$ \\
\hline$/ \mathrm{v} /-/ \mathrm{f} /$ & $\begin{array}{l}\text { ever, university, provide, predic- } \\
\text { tive, save, believe, live, even, have, } \\
\text { every, vacation, Java, live, develop- } \\
\text { ment, innovator, university, invite }\end{array}$ & $\begin{array}{l}\text { provide, conversation, video, motivation, } \\
\text { interactive, revolution, survive, everyone, } \\
\text { giving, deliver, revolution, everything, even, } \\
\text { have, level, evaluate, provide }\end{array}$ \\
\hline
\end{tabular}

sounds substitution on some vowels and diphthongs as displayed in the Figures 1.

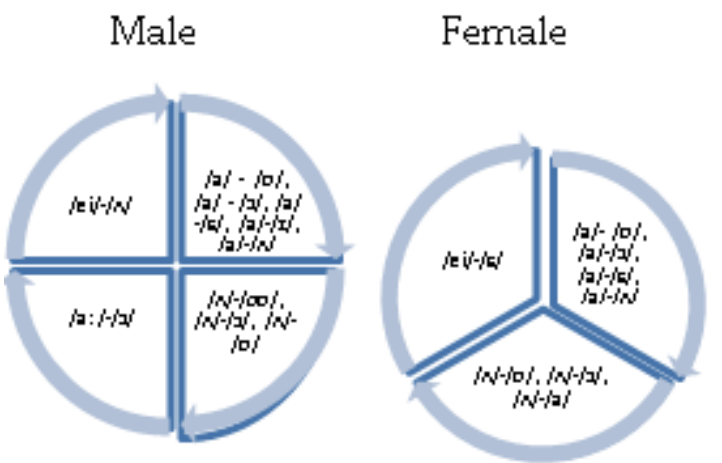

Figure 1. Differences of sounds substitutions on Male and Female Students' pronunciation.

From the Figure 1, the researcher found that male students made more variation on IL errors on the sound substitutions.

\section{CONCLUSION}

The researcher draws some conclusions based on the objective of the research. First, L1 transfer, different form of plural, sound with the same phonetic features but different in distribution, and foreign sound, are source of errors on male and female students. These sources of errors cannot be separated from both male and female college students because both of them come from the same L1, the same environment, and the same obstacles dealing with English pro- nunciation.

Second, both male and female college students have many similarities in producing IL errors. Both of them got difficulty in pronouncing English sounds which have different features compare to Indonesian sounds such as: /i:/, / э:/, /৩:/, /ә:/, /іә/, /uә/, /ov/, /z/, /b/, / $\mathrm{p}^{\mathrm{h}} /, / \mathrm{k}^{\mathrm{h}} /, / \mathrm{v} /$, English foreign sounds such as: $/ æ /, / \theta /, / 3 /$, different rules of pronunciation between English and Indonesian language such as pronouncing the plural sounds.

Third, in producing IL errors on pronunciation, male students seems have more varieties than the female students.

This study focused on the source of IL errors on male and female students' pronunciation, by describing students' source of errors based on gender, the similarities, and the differences between male and female college students' pronunciation. Most the source of these errors found in this study were errors based on the segmental features. Therefore, for the next researcher who is going to conduct the same topic with this study, they can focus on the source of errors based on genders, on supra-segmental features such as linking words, pitch, etc. in order to find deeper information about the source of errors from segmental and supra segmental features.

\section{REFERENCES}

Alahmadi, N., \& Lahlali, M. (2019). The role of learners' gender differences in L2 "Interlanguage" 
errors of intermediate-level saudi language learners. Journal of Arts and Humanities, 2(3), 41-51.

Al-khresheh, M. (2015). A review study of interlanguage theory. International Journal of Applied Linguistics \& English Literature, 4(3), 124-131.

Aziez, F. (2016). An analysis of interlanguage performed by students of an islamic boarding school in tasikmalaya. Academic Journal Perspective, 4(2), 103-122.

Celce-Murcia, M., Brinton, D. M., Goodwin, J. M., \& Griner, B. (2010). Teaching pronunciation: $A$ course book and reference guide. Cambridge University Press.

Elliot, A. R. (1995). Foreign language phonology: field independence, attitude, and the success of formal instruction in spanish pronunciation. The Modern Language Journal, 79(4), 530542.

Fabianto, E., \& Hartono, R. (2015). The effectiveness of comprehensible input and incomprehensible input for enhancing English speaking skill of recount text on male and female students. English Education Journal, 5(2), 63-71.

Gilakjani, A. P. (2011). Why is pronunciation so difficult to learn?.English Language Teaching, 4(3), 74-82.

Gilakjani, A. P. (2012). A Study of Factors Affecting EFL Learners' English Pronunciation Learning and the Strategies for Instruction, International Journal of Humanities and Social Science, 2(3), 119-128.

Gilbert, J. B. (2008). Teaching pronunciation: Using the prosody pyramid. Cambridge University Press.

Gowhary, H., Azizifar, A., \& Rezaei, S. (2016). Investigating English Vowel Reduction in Pronunciation of EFL Teachers of Schools. ProcediaSocial and Behavioral Sciences, 232, 604-611.

Humaini, A. (2016). Penanda jamak. Jurnal Pendidikan Bahasa Arab, 7(1), 1-11.

Jahandar, S. et.al. (2012). A Gender-based Approach to Pronunciation Accuracy of Advanced EFL Learners. International Journal of Scientific \& Engineering Research, 3(6), 34-42. http://www. ijser.org/

Lakof, R. (1973). Language and woman's place. Cambridge University Press, 2(1), 45-80. http://www. jstor.org/stable/4166707

Litosseti, L. (2013). Gender \& language. Routledge.

McMahon, A. S. (2016). An introduction to English phonology. EUP.

Ramelan. (1999). English phonetics (6 $6^{\text {th }}$ ed.). IKIP Semarang Press.

Sakhiyya, Z. (2018). English as a lingua franca: Perspectives for English language teaching and for teacher education. Advances in Social Science, Education and Humanities Research (ASSEHR), 188, 117-119.

Wati, A., Bharati, D. A., \& Hartono, R. (2014). The scientific approach in teaching speaking for various texts. English Education Journal, 4(2), 145-150.

Young, D. J., \& Oxford, R. (1997). A gender-related analysis of strategies used to process written input in the native language and a foreign language. Applied Language Learning, 8(1), 43-73. 